\title{
PRÁTICA PEDAGÓGICA EM DANÇA: \\ O IJEXÁ COMO PROPULSOR DA PRODUÇÃO DE CONHECIMENTO EM ARTES
}

\section{Rodrigo Lemos Soares}

\begin{abstract}
Resumo
Ilexá é uma cidade do Estado de Osun. Assim como as demais manifestações culturais abarcadas em solo brasileiro o Ijexá apresenta caracteres diferentes do praticado em solos africanos. De todos os toques sacros do Candomblé, ele é provavelmente o mais suave e cadenciado, emoldurando a dança dengosa e sensual de Oxum e Logum. A escrita deste texto parte dessa premissa para pensar uma prática pedagógica em danças afro.
\end{abstract}

Palavras-chave

Ensino de dança. Ijexá. Danças Afro. Educação. Corporalidades

\section{Primeiros passos...}

Ilexá é uma cidade do Estado de Osun (Oxum). Assim como as demais manifestações culturais abarcadas em solo brasileiro o Ijexá apresenta caracteres diferentes do praticado em solos africanos. De todos os toques sacros do candomblé de Ketu, o Ijexá é provavelmente o mais suave. O ritmo é suave e cadenciado, emoldurando a dança dengosa e sensual de Oxum e Logum. De ritmo dos terreiros, o Ijexá acabou também chegando ao carnaval, a partir da criação dos afoxés baianos, no final do século XIX. As danças de Oxum e seu filho Logun-Edé, simulam um banho vaidoso nas águas dos rios, enquanto se miram no espelho e seduzem a todos de forma faceira e, vez por outra, enganadora.

O toque do Ijexá busca descrever, então, a cadência sedutora e feiticeira das águas. A composição coreográfica, oriunda da prática pedagógica em dança, combina elementos destes três orixás, no sentido de compor um olhar que aproxima os pontos em diálogo das corporalidades de cada figura. Para tanto, escolhi abordar as marcações, saltos e deslocamentos característicos, dos mesmos. Além disso, recorri a uma progressão que foi dos passos básicos, momentos específicos das danças abordadas, até o sincretismo religioso que as envolve, dialogando com fazeres no Brasil e em solo africano. Este texto, então, é uma sistematização de uma aula de dança afro, ocorrida em um curso de licenciatura em dança, focando nos processos de aprendizagem, bem como, em epistemologias que envolvem o campo da educação, principalmente, pensando em 
pedagogizações decolonizadoras. Para tanto, além da escrita reflexiva deste texto, apresento ao final do mesmo tanto o plano de aula, quanto o material pedagógico utilizado.

\section{Ijexá: situando o terreno e os terreiros...}

Ilexá é uma cidade do Estado de Osun (Oxum) pertencente as tradições dos Yorubá, já foi a capital do reino de Oyó. Dentre as cidades e aldeias desta região da Nigéria, Benin e Togo. Ilexá é a maior, além de ser um centro agrícola e comercial. Segundo as lendas dos Ijexás, menciona que a origem deste povo vem de um filho de Oduduwa, chamado Obokun. Segundo Reginaldo Prandi (2005)

São chamados sudaneses os povos situados nas regiões que hoje vão da Etiópia ao Chade e do sul do Egito a Uganda, mais o norte da Tanzânia. Seu subgrupo denominado sudanês central é formado por diversas etnias que abasteceram de escravos o Brasil, sobretudo os povos localizados na região do Golfo da Guiné, povos que no Brasil conhecemos pelos nomes genéricos de nagôs ou iorubás (mas que compreendem vários grupos de língua e cultura iorubá, entre os quais os das cidades ou regiões de Oió, Queto, Ijebu, Egbá, Ifé, Oxogbô, Ijexá etc.) (PRANDI, 2005, p. 2).

Segundo Prandi (2005), “[...] os precursores dessas religiões foram negros das etnias nagôs ou iorubás, especialmente os das cidades e regiões de Oió, Lagos, Queto, Ijexá, e Egbá, e os povos Fons, aqui chamados Jejes, sobretudo os Mahis e os Daomeanos" (p. 165). Usa-se a expressão "Kabó ó!", porém a mesma, não reflete apenas um abrir de portas do Ijexá, mas um convite à discussão de temas que reflitam o resgate e a preservação da cultura afro-descendente no Brasil, de modo a contribuir para romper com preconceitos. Carneiro (1967) expõe que “[...] os Orixás nagôs são, em geral, personagens evemerizados, que representam as forças elementares da natureza ou as atividades econômicas que se entregavam os negros na região do Níger" (CARNEIRO, 1967, p. 79).

[...] Em território africano, o culto aos Orixás era constituído de forma regional e patriarcal. Numa disposição regional tem-se a territorialização do culto, o qual se ligava a um Orixá específico, por exemplo: em Oió cultuava-se Xangô, Orixá da justiça, do fogo e dos raios, já em Irê o domínio religioso era de Ogum, divindade ligada à guerra e a tecnologia (DA SILVA, 2010, p. 101). 
Esta mesma autora afirma que "[...] $\mathrm{Na}$ historiografia sobre os nagôs são recorrentes afirmativas de que a mulher sempre deveria cultuar o Orixá do pai e de forma consecutiva o Orixá daquele que ela coabitasse em relações matrimoniais" (DA SILVA, 2010, p. 101). Eduardo Miranda (2014) afirma que,

[...] o Legado Ancestral Africano como saberes culturais dos nossos ancestrais africanos e afro-brasileiros que não necessariamente são cultuados nos espaços dos Terreiros, por exemplo, o fato de vestir a indumentária com influências africanas, dançar o ritmo Ijexá, cantar músicas em Iorubá não enquadra o sujeito como adepto do Candomblé e, sim, como realimentador dos elementos culturais dos seus ancestrais africanos (MIRANDA, 2014, pp. 39-40).

Ainda, para Miranda (2014), “[...] O Ijexá embala os corpos-territórios os quais grafam em diversas direções as linhas policromáticas das matrizes africanas e afrobrasileiras" (MIRANDA, 2014, p. 159). No entanto, assim como as demais manifestações culturais abarcadas em solo brasileiro o Ijexá apresenta características diferentes do praticado em solos africanos. Este fator, por sua vez, não fere, mas enriquece os cultos, a partir das múltiplas manifestações de dança, música, vestimentas e mesmo ritos.

\section{Como chega ao Brasil?}

Através de Mejigã, africana do povo Ijexá, trazida à força para o Brasil, para ser escrava. Seu nome de batismo em solo brasileiro foi Inês Maria. Cultuava Oxum Abalô, por ser filha mitológica desta orixá. No entanto, “[...] os luxos da Oxum foram substituídos pela corrente, pela cafua, pela senzala". Ainda, segundo esta história, Inês trouxe consigo o fato de acreditar na Liberdade, em uma forma de descendência sem as marcas do ferro da escravidão. Ainda na senzala, conheceu Leocádio Figueiredo (negro brasileiro de origem angolana) e com ele, Inês gerou Maria Figueiredo (única filha). Era a esperança de sobrevivência do axé ijexá nas terras do Brasil, na Região do Cacau. Isso implica determinadas linhas de ação e compromissos da própria casa, que traz consigo as marcas da nação ijexá, que se distingue das demais pelo ritual, pelos toques, pelos cânticos e pelas danças. Em Miranda (2014) “[...] o ritmo Ijexá apresenta uma sonoridade mais lenta com características fúnebres, de cortejo, com passos lentos e marcados, ressaltando que no Candomblé o velório também é festa” (p. 106). 
Segundo Miranda (2014) “[...] a importação dos nagôs foi intensificada, posto que as guerras internas nos reinos de Oió, Queto, Egba, Yagba, Ijexá, Ijebu, Ifé desencadeou a exportação de dezenas de homens e mulheres em condições de escravos para o solo baiano" (MIRANDA, 2014, p. 105). Este cenário, foi propulsor daquilo que entendemos por processos de miscigenação. Além disso, possibilitou intercâmbios culturais que resultam na mescla de culturas e saberes que compõem nosso arcabouço históricocultural, propiciando que algumas práticas seja denominadas como afro-brasileiras, considerando nessa esteira: as danças, as músicas, as religiosidades, dentre outras manifestações. Contudo, ao trabalhar com estas temáticas compreende-se como necessárias as explanações acerca dos processos de rapto, escravização e inúmeras tentativas de invisibilização das culturas desses povos.

\section{Caracterizando...}

De todos os toques sacros do candomblé de Ketu, o Ijexá é provavelmente o mais suave. Vale esclarecer, para inicio de conversa, que a palavra Ijexá origina-se do vocábulo Ijèsá, uma subdivisão da etnia iorubá e o nome da cidade nigeriana que é considerada o berço do grupo. Nessa cidade se cultuam, sobretudo Oxum e Logun-Edé - e o Ijexá designa o ritmo das danças principais desses orixás. Tocam-se, também, ijexás (ainda que não seja o ritmo predominante) para Exu, Osain, Ogum, Oyá, Obá, Oxalá, Orunmilá. O Ijexá é apresentado nos terreiros somente com as mãos, dispensando-se o uso dos aguidavis (as baquetas de percussão). O ritmo é suave e cadenciado, emoldurando a dança dengosa e sensual de Oxum e Logum. Para Lopes (2005) '[...] os cânticos são tradicionalmente acompanhados por atabaques do tipo 'ilu', percutidos com as mãos, além de agogôs e xequerês, no ritmo conhecido como 'ijexá"” (LOPES, 2005, p. 14). Miranda (2014) ratifica expondo que,

[...] o agogô é um instrumento muito importante por ser o responsável por dar o tom para os demais artefatos musicais, tanto que nos ensaios, assim como no desfile na Micareta, o primeiro corpo-sonoro a compor o território pombalense advém do contato entre a baqueta de metal com as campânulas do agogô, anunciando a entonação rítmica do Ijexá com linhas sonoras invisíveis, mas repletas de simbologias grafadas no campo da comunicação visual. O atabaque é outro instrumento representativo dos afoxés com tamanho reduzido, 
possuindo encouramento em ambas as bocas do instrumento. São denominados de Runs, Rumpis e Lés ${ }^{1}$ (MIRANDA, 2014, p. 150).

De ritmo dos terreiros, o ijexá acabou também chegando ao carnaval, a partir da criação dos afoxés baianos, no final do século XIX. Algumas pessoas e até mesmo alguns livros fazem certa confusão ao citar o afoxé como um ritmo. O afoxé é o cortejo - o ritmo que emoldura o cortejo é o ijexá. A expressão afoxé, inclusive, vem do iorubá àfose (encantação pelo som, pela palavra). $\mathrm{O}$ afoxé Filhos de Gandhi, fundado por ogãns de candomblé na década de 1940, até hoje se apresenta no carnaval ao som do ijexá - e começa sempre o cortejo tocando para Logun-Edé. Os que já viram um xirê certamente se recordam das danças de Oxum e seu filho Logun-Edé, simulando o banho vaidoso nas águas dos rios, enquanto se miram no espelho e seduzem a todos de forma faceira e, vez por outra, enganadora. O toque do Ijexá busca descrever, por isso, a cadência sedutora e feiticeira das águas.

[...] a arte de dançar embalada pelo som do Ijexá, solicita ações corporais que transmudem o óbvio e assumam formas circulares e tenha o chão/solo como ingrediente somatório na composição das danças. O contato com o chão é tão importante para a cultura afrobrasileira que podemos visualizar nos traços gráficos os pés descalços dos bailarinos, pois as energias advindas do solo são relevantes para a realimentação do axé. Ademais, esse tipo de bailado procura estabelecer uma base móvel que garanta a execução perfeita dos bailados ensaiados durante todo um ano, ou seja, essa concepção também provém de um desenho projetual (MIRANDA, 2014, p. 148).

Pode-se dizer que as expressões da cultura corporal afro-brasileira são um exemplo da vivência de uma corporeidade plena. Segundo Guerra (2008), “[...] o africano canta e dança nos diversos eventos da comunidade a que pertence e das mais variadas formas que a criatividade e a espiritualidade lhe concedem, mas, especialmente para celebrar a vida!" (GUERRA, 2008, p. 24). Para mesma autora, a cultura corporal africana manifesta-se: na “[...] dança, corpo, movimento, sons, ritmos, palavras, contagiando e penetrando no seu eu e nos outros seres a sua volta, o ímpeto mais sublime de 'energia vital' que no Brasil é chamado de Axé” (GUERRA, 2008, p. 25). Para Souza (2000),

\footnotetext{
${ }^{1}$ Especificamente $\boldsymbol{R U} \boldsymbol{M}$ é o maior dos atabaques e possui o registro grave; $\boldsymbol{R U M P I}$ é o segundo e possui o registro médio e $\boldsymbol{L} \hat{\boldsymbol{E}}$ é o menor e possui o registro agudo. Além dos tambores usam-se também os Gãs (sinos). Além destes, é possível encontrar: Agbê (Xequerê), a caixa (uma espécie de tambor), o Gonguê (lembra um sino ou um agogô) e as Alfaias (bombos ou zabumbas).
} 
No candomblé as danças são caracterizadas pela função que exercem de não impressionar o público, mas de demonstrar um sentido para a vida terrena através da síntese dos gestos e movimentos dos orixás. Já na dança afro, uma boa parte de seu conteúdo e da sua forma sofre considerável criatividade para causar impressão e, quando os mitos são representados e interpretados por um solista, isto é, um único dançarino-ator em cena, a dança poderá ser executada por improvisos (SOUZA, 2000, p. 305).

Nesse excerto, encontram-se algumas características da cultura afro, como a criatividade, a valorização da ritualidade e a presença corporal plena. Diante dessas características como a escola pode incluir a dança afro-brasileira em seus currículos? Além das danças artísticas, encontra-se as danças midiatizadas e comercializadas, como o axé. Para Silveira, Cardoso e Sabbag (2008) os “[...] dançarinos de axé possuem uma visão mais voltada à exposição corporal, de realizar movimentos perfeitos, mostrando seu corpo, também perfeito e sempre voltados à sensualidade, costumam chamar a atenção através da forma de atuar com seu corpo" (SILVEIRA, CARDOSO, SABBAG, 2008, p. 04).

\section{Sobre Logum Odé ${ }^{2}$ Ossanha e Oxumaré: incursões nas margens...}

Segundo Prandi (2016) Logum Edé é metade Oxum (rio) e metade Erinlé Oxóssi (mato), porém suas metades nunca podem se encontrar. Ele habita estas duas paisagens, em momentos distintos. Possui um ofá (arco e flecha - herdados do pai) e abebé (espelho - herdado da mãe). Vaidoso como seus pais era "considerado o príncipe do encanto e da magia" (idem, p. 137). Devido as suas características era considerado uma criança de personalidade dupla e assim, passava metade do ano com seu pai e a outra com sua mãe, porém não respeitava nem a um, tampouco a outra, por crer na sua vaidade. Erinlé não sabia que Logum Odé era seu filho e se apaixonara por ele, dada capacidade sedutora do menino.

Para Barbosa Júnior (2014) Logun-edé vivia nas águas como mulher e nas matas como homem apresentando traços hermafroditas. Quando no seu "aspecto feminino usa saia cor-de-rosa e coroa de metal e no aspecto masculino, usa capacete de metal, arco e flecha, capangas e espada" (JÚNIOR, 2014, p. 42). Dentre suas lendas estão: Logum Odé é salvo das águas; Logum Odé devolve a visão a Erinlé; Logum Odé rouba segredos de Oxalá e Logum Odé é possuído por Oxóssi.

\footnotetext{
${ }^{2} \mathrm{O}$ mesmo orixá pode aparecer com escritas como: Logum Odé, Logun-edé.
} 
Já Ossanha ${ }^{3}$, “[...] é filho de Nanã e irmão de Oxumaré, Euá e Obaluaê, era o senhor das folhas, da ciência e das ervas, o orixá que conhece o segredo da cura e o mistério da vida” (PRANDI, 2016, p.153). Para Júnior (2014) em alguns terreiros “[...] este orixá é cultuado como Iabá (orixá feminino)" (JÚNIOR, 2014, p.70). Ao lado de Oxóssi rege as florestas. Dentre suas lendas estão: Ossaim recusa-se a cortar as ervas miraculosas; Ossaim dá uma folha para cada orixá; Ossaim cobra por todas as curas que realiza; Ossaim vinga-se dos pais por o deixarem nu; Ossaim vem dançar na festa dos homens e Ossaim é mutilado por Orunmilá.

Oxumaré, “[...] filho mais novo e preferido de Nanã” (BARBOSA JÚNIOR, 2014, p.90). Segundo este mesmo autor, por evocar renovação constante Oxumaré pode “[...] diluir a paixão e o ciúme em situações onde o amor perdeu terreno" (idem. p. 91). Além disso,

[...] nos seis meses em que assume a forma masculina, tem-se a regulagem entre chuvas e estiagem, uma vez que, enquanto o arco-íris brilha, não chove. Por outro lado, o próprio arco-íris indica as chuvas em potencial, prova de que as águas estão sendo levadas para o céu para formarem novas nuvens. Já, nos seis meses em que assume a porção feminina, tem-se a cobra a rastejar com agilidade, tanto na terra quanto na água (BARBOSA JÚNIOR, 2014, pp. 90-91).

Dentre suas lendas estão: Oxumaré desenha o arco-íris no céu para estancar a chuva; Oxumaré fica rico e respeitado; Oxumaré transforma-se em cobra para escapar de Xangô; Oxumarê usurpa a coroa de sua mãe Nanã e Oxumarê é morto por Xangô.

\section{Entre danças, movimentos e expressões das mitologias dos orixás...}

Referente aos ritos religiosos Ikeda (2016) expõe que:

Trata-se do Ijexá originalmente nos cultos de candomblé (iorubá), nos quais sempre se relacionam o som (música), a expressão corporal (dança) e dramática (personagens) e o ritual religioso. Canta-se em dialeto africano predominantemente, mesmo que apenas como referência simbólica, para Oxum principalmente (Nigéria), mas também para outros orixás. É música de culto religioso (funcional), de tradição oral, que propicia incorporação (espiritual) ao iniciado, sustenta o passo e a dança do orixá incorporado. Propicia o "convívio" com a espiritualidade, os antepassados e os seguidores (IKEDA, 2016, pp. 31-32).

A dança, “[...] que é de transe, adquire um duplo papel: de um lado dá-se a demonstração da experiência mística do fiel na transformação interior, do outro, por meio dos passos das coreografias, conta a história mítica e revela a visão de mundo do

\footnotetext{
${ }^{3} \mathrm{O}$ mesmo orixá pode aparecer com escritas como: Ossanha, Ossaim, Ossãe, Osayn.
} 
grupo” (BARBARA, 2002, p.02). “[...] A dança não é uma simples e fria repetição automática de gestos ou de coreografias, mas uma nova experiência do corpo, um corpo que passou por todo um processo ritual" (BARBARA, 2002, p.08). As danças dos orixás, segundo a autora, sempre representam suas histórias e mitologias, no entanto, elas sofrem com as interferências das vidas mundanas dos praticantes. Embora possuam caracteres específicos de cada orixá, para que os mesmos ocorram, faz-se necessário uma adaptação a um corpo específico, o que não fere a dança ou mitologia representada, mas expõe as diferenças entre os mundos mitológicos e as vivências cotidianas do hoje.

\begin{abstract}
A música e a dança como parte integrante do cotidiano dos negros e a presença do candomblé observável no dia a dia, nos cantos (onde ofereciam serviços), nas lojas (onde habitavam coletivamente), ou nos terreiros (onde cultuavam seus deuses). Além de atividades ligadas ao candomblé, os negros elaboravam ainda uma série de divertimentos que também envolviam estas artes [...] A presença de instrumentos percussivos e os ritmos que acompanhavam danças e cantos, tanto no espaço sagrado quanto no profano, indicavam certa indefinição entre as manifestações lúdicas e religiosas (GUERREIRO, 2000, p. 67).
\end{abstract}

Barbara (2002) demarca que ao ocorrer desse modo, a dança em si não ocorre por repetições, mas sim por leituras possíveis, ou seja, transcrições corporais que ocorrem variando de um corpo para o outro, isto é, mesmo que dois sujeitos sejam filhos de um mesmo orixá eles possivelmente dançarão de modos distintos. Para Machado (2014) “[...] a dança, portanto, faz parte de uma concepção muito maior de movimento que só pode ser pensada a partir das cosmologias respectivas, seja de matriz Iorubá, Jeje, Efon, Bantu, Ijexá ou tantas outras" (MACHADO, 2014, p. 21).

No âmbito das religiões afro-brasileiras, por exemplo, a dança é um elemento crucial. Ela não está separada da cosmovisão inerente a esses sistemas de pensamento, uma vez que pares como corpo e espírito, corpo e pensamento não se dão como termos opositivos e descontínuos como na cultura ocidental de matriz cristã. [...]E quando falamos em corpo e dança talvez estejamos categorizando elementos que em culturas e epistemologias não ocidentais não são categorizáveis tal como a ocidentalidade os entende; assim, o faço como mero recurso de referência, como o dizer com essas palavras me impele a fazer (MACHADO, 2014, p.21).

$\mathrm{Na}$ dança de Ossain, por exemplo, segundo Cardoso (2006) os movimentos imitam alguém bebendo algo, seriam os remédios que este orixá plantou. Porém, os 
movimentos dependem das letras entoadas. "[...] os gestos coreográficos, no decorrer da dança, seguem o significado contido na letra da canção [...]" (CARDOSO, 2006, p. 248). Isso porque, “[...] no candomblé, mito, dança e música, estão intimamente interligados" (CARDOSO, 2006, p. 250).

$\mathrm{Na}$ relação música-instrumental-dança, o rum emite frases musicais que podem ser tanto uma resposta a uma determinada frase coreográfica quanto um pedido para que se faça uma frase coreográfica. Essas frases coreográficas, por sua vez, são representações dramáticas, são gestos que imitam as características do orixá, principalmente, ditadas nos mitos. Por essa razão, faz-se importante o conhecimento dos mitos dos orixás, pois por intermédio deles passamos a compreender os significados contidos nas frases coreográficas (CARDOSO, 2006, pp. 250-251).

Depois do Exú, que é o mensageiro geral, Ogum é o primeiro orixá a ser dançado. Seus movimentos referendam a guerra. Como guerreiro que é, ele chega abrindo e protegendo os caminhos para os próximos deuses e deusas chegarem (CARDOSO, 2006). Em suma,

[...] não se pode homogeneizar as concepções de dança e corpo, que, em culturas de matriz africana, por exemplo, vinculam-se a epistemologias e racionalidades que envolvem maneiras singulares de perceber/conhecer o mundo, impondo, inclusive, limites a esse conhecimento - não se pode compreender tudo, na dupla acepção do termo (MACHADO, 2014, p. 21).

Alio-me a ideia defendida pela professora Márcia Strazzacappa (2001) ao mencionar que a música e a dança para além de estarem associadas sofrem influências das regiões específicas onde se desenvolvem, porém são componentes das culturas locais dos povos. No entanto, para Cuche (1998), esses costumes, hábitos ou valores somente podem ser compreendidos se forem relacionados ao seu contexto cultural, ao seu tempo e seu povo, passado pela oralidade.

A oralidade como ferramenta de registro atingiu muitos campos da vida africana, o que deixou como legado para a dança, mesmo a afrobrasileira, uma grande lacuna quando falamos em sistematização ou mesmo um registro formal de um saber que há muito vem sendo repassado somente pelas vozes do corpo e do gesto (AUM MAGIC, 2017, s/p).

Para os africanos “[...] o corpo é, por excelência, o local da memória, o corpo em performance, o corpo que é performance" (CARDOZO, 2006 apud. AUM MAGIC, $2017, \mathrm{~s} / \mathrm{p})$. O corpo é forjado, ao mesmo tempo em que produz identidades. 
A estética propriamente reconhecida da música negra baiana é mais uma construção da sua identidade do que elemento de status definidor de sua conduta meramente imagética. Os instrumentos percussivos, a ginga sonora, a simbologia das danças e coreografias, e os grafismos espalhados pelo cenário (a rua), onde o corpo é uma das ferramentas dessa construção, são sintomas das mestiçagens que buscam a valorização do negro como sujeito formador de sua própria condição história (FILHO, 2016, p. 37).

Os corpos, as identidades são produtos de subjetividades constituídas em meio aos campos e relações de poder que estão implicadas nas memórias, estéticas, movimentos e sons específicos das culturas afro, em específico, de suas religiosidades.

As especificidades da dança afro são justamente essa trajetória que ela realiza a partir da tradição oral africana, resguardando elementos do drama ritual (homenagem aos deuses, à natureza, ao líder, ao cotidiano), e como qualquer dança de qualquer comunidade é representada principalmente pelos movimentos advindos dos rituais (não necessariamente os religiosos, mas sim os culturais), acompanhados por forte influência dos instrumentos e ritmos africanos. Dança afro são os movimentos corporais ritmados que performatizam elementos das matrizes tradicionais orais africanas (CARDOZO, 2006 apud. AUM MAGIC, 2017, s/p).

A dança de matriz africana é entendida e utilizada como uma linguagem corporal socialmente contextualizada, que conta histórias, que descreve vivências, recria o mundo (SABINO; LODY, 2011 apud. AUM MAGIC, 2017, s/p).

\begin{abstract}
A dança afro incorpora a dança dos orixás sem o caráter ritualístico ou litúrgico dos candomblés, adaptada para o palco a partir do terreiro. Nesse processo mudam-se os objetivos: a dança não é mais instrumento para se atingir o transe religioso o que torna os movimentos repetitivos ao som dos atabaques. A coreografia constrói uma grande variedade de movimentos corporais em rápida sequência procurando ocupar todos os espaços do palco. A mesma lógica se aplica à dança do maracatu, lundu, jongo, cafezal, caxambu, que também fazem parte da base coreográfica da dança afro (LIMA,1995 apud. AUM MAGIC, 2017, s/p).
\end{abstract}

A representação do orixá torna-se então diferenciada no culto e no palco. No culto, ela é dançada pelos membros da comunidade religiosa, com seus corpos distintos e não necessariamente com treinamento específico de dança, limitando-se ao enfoque religioso e ritual do movimento dançado. Para o palco, a movimentação de cada orixá foi trabalhada por Mercedes Baptista durante sua pesquisa de construção da técnica da dança afro-brasileira, o que dá à movimentação singularidades específicas a serem desenvolvidas pelo corpo treinado do bailarino. 
Assim, a identidade africana não é apagada, mas ela adequa-se as tramas de poder, sendo expressadas pelos seus cânticos, pois conforme Hall (2006): "essas identidades não estão impressas em nossos genes. Entretanto nós efetivamente pensamos nelas como se fossem parte de nossa natureza essencial". Pensando por esse viés, a identidade afrobrasileira acaba sendo definida nesses espaços socioculturais, embora haja uma desterritorilização de espaços, percebe-se essa fragmentação, onde as identidades produtos de uma representação, no que tange as suas práticas de resgate de origem, agregando assim, símbolos as suas músicas, cânticos, danças, entre outros (SOUZA et. al. 2016, p. 556).

As danças dos orixás são executadas sob um ritmo específico para cada divindade do panteão africano e cada uma terá traços coreográficos próprios. As coreografias das danças dos orixás remetem à mitologia de cada orixá, representando seus feitos, suas características individuais, suas histórias. Os orixás são comumente representados cenicamente portando uma ferramenta, uma espécie de insígnia que "identifica o caráter, a função e a história dos orixás" (SABINO; LODY, 2011 apud. AUM MAGIC, 2017, s/p).

As Danças Afro que trabalham diretamente com a religiosidade são denominadas Dança dos Orixás, que está associada às religiões africanas. Assim como a dança, as religiões foram transformadas pelas práticas e influências do Brasil, tornando-se religiões afro-brasileiras. Os negros utilizaram estratégias para aproximar suas divindades e reelaborar seus mitos, ritos e sistemas religiosos (SANTOS, 2012 apud. COELHO, 2017, p.40).

José Ramos Tinhorão (2012) resgata diferentes fatos culturais que compõem uma ideia de base da formação de uma manifestação da música brasileira, especificamente a popular e negra. Na obra podem ser observadas algumas marcas, ecos das cantorias durante trabalho dos escravos em diferentes contextos, sons oriundos de muitos territórios das Áfricas, mas miscigenados com culturas expressas no Brasil. Tais manifestações, apresentadas pelo autor foram possíveis, mesmo reprimidas pelas autoridades das épocas. Estas marcas, portanto, foram se consolidando de forma híbrida, fundindo-se em uma diversidade sonora que mescladas a ritmos e coreografias conseguiram aos poucos, deliberar seus espaços em meio aos contextos da branquitude, por sua vez, conseguiram se estabelecer em meio as expressões sonoras e danças.

\section{Entre tatos e contatos: caminhos trilhados e encontros em suspenso}

A construção deste texto percorreu diferentes caminhos e redes de saber. Em um primeiro momento a recorrência foi aos documentos publicados (matérias de 
reportagens, artigos, Teses e Dissertações) partindo de uma premissa de que o trabalho, a partir destes artefatos auxiliaria no entendimento de um aporte teórico que subsidiasse os caminhos outros, das fases por vir do trabalho. Delimitados os materiais a serem utilizados a recorrência foi a sujeitos, grupos, instituições, as quais tivessem alguma conexão com o Ijexá, com o parafolclóre.

Desse modo, recorri a diferentes instâncias preconizando sanar as dúvidas suscitadas nos primeiros arquivos estudados, foi então que realizei diferentes tentativas de contato com os nomes abaixo listados. Destaco que todos os contatos foram realizados pelo site de rede social facebook. Os acessos foram respectivamente assim transcorridos: a. Alaketu - Companhia de Dança (não visualizou nenhuma das tentativas); b. Anderson Hassys de L'Oyá (demonstra não ter acessado seu perfil); c. Asé Ijexá $^{45}$ (grupo fechado) (visualizou a mensagem, porém não retornou); d. Cia. De Teatro e Dança Afro Aiê Orum ${ }^{6}$ (aparentemente não acessaram o perfil do grupo, visto que a última postagem ocorreu há algum tempo); e. Diego Bernardes Ayraiberu ${ }^{7}$ (visualizou a mensagem, no entanto, ainda não retornou); f. Ilê Axé Omim Ijexá ${ }^{8}$ (não visualizou a mensagem); g. Instituto Cultural Filhos de Aruanda (retornaram o primeiro contato no dia 23 de junho de 2018 estou aguardando retorno para marcar entrevista); h. Nação Jeje-Ijexá ${ }^{9}$ (ainda não visualizou o contato); i. Oxum, Rainha do $\operatorname{Ijexá}^{10}$ (aparentemente não receberam a mensagem).

Como pode ser observado, existem diferentes expectativas de grupos e sujeitos para que este trabalho tenha prosseguimento sob outros aspectos, porém outras tentativas estão sendo encaminhadas, a fim de receber alguma forma de manifestação dos mesmos. Tendo em vista o tempo estipulado para execução e realização das pesquisas e execuções das propostas pedagógicas todos os contatos foram reforçados, no mínimo duas vezes. Dadas essas contingências da pesquisa o texto foi desenhandose, a partir dos retornos obtidos.

Dito isso, de antemão, afirmo que as danças em si, trabalham com as noções identitárias. Assim, faz-se necessário grifar o caráter momentâneo, não fixo e

\footnotetext{
${ }^{4}$ Os nomes destacados em Negrito com demarcação em Itálico são os que retornaram às mensagens, ainda no prazo de fechar este texto para submissão.

${ }^{5}$ Sobre o grupo ver: $<$ https://www.facebook.com/groups/246010619100692/?ref=br rs $>$

${ }^{6}$ Sobre a Cia. Ver: <https://www.facebook.com/Cia-De-Teatro-e-Dan\%C3\%A7a-Afro-Ai\%C3\%AAOrum-272218486269956/>

${ }^{7}$ Sobre o perfil deste sujeito ver: $<$ https://www.facebook.com/diego.bernardes.355?hc_ref=SEARCH $>$

${ }^{8}$ Sobre o grupo ver: $<$ https://www.facebook.com/groups/599459710233142/?ref=br_rs $>$

${ }^{9}$ Sobre a instituição ver: $<$ https://www.facebook.com/NacaoJejeIjexa/?ref=br_rs $>$

${ }^{10}$ Sobre o grupo ver: $<$ https://www.facebook.com/oxumrainha/?hc_ref=SEARCH\&fref=nf $>$
} 
contingente do texto apresentado. Este mesmo trabalho pode ser relido e transformado pela gama de leituras que ainda necessitam ser realizadas, a fim de complementar as leituras e os olhares sobre o Ijexá e os orixás apresentados. No entanto, no próximo tópico abordo mais a discussão sobre às danças e a produção de conhecimento firmados no título do texto.

\section{Entre saberes instituídos e a produção de conhecimentos sobre danças}

Enfatizo aqui o papel dessas manifestações como veiculadoras de conhecimentos que pedagogizam os corpos, a partir do momento que ensinam sobre comportamentos, produzindo, assim, subjetividades, identidades e saberes. A afirmativa deve-se pelo diálogo com Steinberg e Kincheloe (2001) ao indicarem que pedagogia cultural supõe que a educação ocorra "[...] numa variedade de áreas sociais, incluindo, mas não se limitando à escolar. Áreas pedagógicas são aqueles lugares onde o poder é organizado e difundido" (STEINBERG; KINCHELOE, 2001, p.14). Envolver às danças afro como um potente artefato pedagógico dá-se por perceber que as trajetórias destes grupos, articulados com suas experiências de pertencimento e produção de sujeitos nestes afetam diretamente os modos como nos constituímos sujeitos (HENNING; HENNING, 2012). Nessa perspectiva, é possível lançar mão àquilo que Foucault (2005, p. 11) pontua como “[...] saberes sujeitados", isto é, que estão a nossa volta, que foram construídos há longa data, mas que são ocultados, desqualificados, por vezes, não entram na ordem do dizível, mas que podem apresentar-se como uma potente ferramenta para/de discussão.

Recorro a Geertz (2008), ao afirmar que as descrições devem ser detalhadas, no intuito de diferenciarmos as narrativas, símbolos, expressões, ambientes, as cronologias, as culturas e as condutas do grupo social pesquisado. É necessário esmiuçar os significados culturais. A partir dos contatos com os sujeitos dos perfis dos sites de redes sociais, mencionados acima, é possível perceber a potência dos saberes produzidos por estes sujeitos, para problematização das danças afro, como uma produção de conhecimento (HENNING; HENNING, 2012). Para todos os sujeitos as danças são repletas de conteúdos que formam e forjam o que entendemos por culturas africanas, ainda que não se chegue a algum tipo de totalidade. Segundo Bosi (2008) estes apontamentos demarcam "[...] aquilo que é essência da cultura, o poder de tornar presentes os seres que se ausentaram do nosso cotidiano" (BOSI, 2008, p. 25). Sobre os saberes e fazeres das danças, vejamos os quadros abaixo: 
[...] Primeiramente vocês precisam pegar o ritmo nas mãos, para emanar energia durante as palmas, nos pontos. Precisam cantar os pontos para que a energia flua na corrente e que isso chegue à assistência. Precisam deixar os compassos movimentarem seus corpos - assim óh - para um lado e para o outro, pois isso é uma festa para as entidades, eles estão chegando na terra e assim como todos nós quando chegamos em algum lugar querem ser bem recebidos. (ASÉ IJEXÁ - 17/07/2018) ${ }^{11}$

[...] A sacerdotisa da casa, após ensinar sobre os significados dos movimentos vai narrando as mitologias das entidades dos filhos mais velhos da casa (nesse sentido, o mais velho não é em idade, mas sim em tempo de casa, de desenvolvido). Ao longo das batidas do tamboreiro ela vai induzindo sensações. Segundo ela "os cavalos devem dançar conforme a vida da sua entidade, sua feitura e desenvolvimento no corpo daquele sujeito" (DIEGO BERNARDES AYRAIBERU - 24/07/2018)

[...] Não preparo vocês para serem bailarinas, mas sim para saberem receber suas entidades. Vai de passo em passo, primeiro estuda a História da religião, quando souberes das tuas entidades, quem são elas, estuda algo sobre elas e isso tudo só tem a te ajudar, porque elas perceberão que tu estás pronta para recebê-las. Daí os movimentos vão acontecendo e saindo conforme elas vão te doutrinando e dominando teu corpo. É por isso, que com o tempo alguns de vocês mudam o jeito de chegada dos seus exus e pombagiras. (INSTITUTO CULTURAL FILHOS DE ARUANDA - 26/07/2018).

[...] Com o tempo, o povo da assistência já sabe se vocês estão prestes a incorporar, se as entidades de vocês estão bem ou viradas. Os movimentos de vocês falarão tudo isso e deixarão vocês expostos. [...] vai aparecer nos movimentos de vocês. É a mesma coisa quando vocês chegam aqui em casa, eu percebo aqueles que querem ficar quietos, os que querem fazer alguma brincadeira, aqueles que só no abraço dizem tudo (todos riram). Viram, isso é muito importante. (NAÇÃO JEJE-IJEXÁ - 30/07/2018).

Partindo desses quatro excertos, os terreiros são entendidos, nesta pesquisa, como instituições culturais. Neles ocorrem inúmeras práticas ritualísticas que influenciam nos modos como os sujeitos se colocam no mundo (CAPUTO, 2012). A educação nestes espaços ou campo desta pesquisa está assentada em uma premissa de que: “[...] as cosmologias das religiões de matriz africana são concebidas num princípio tridimensional simbiótico entre homem-natureza-fé" (SANTOS; GONÇALVES, 2011, p. 14). Nesse sentido, os saberes que são repassados nestes locais perpassam essa trilogia, uma vez que é ela que orienta os caminhos a serem seguidos nos terreiros.

$\mathrm{O}$ fato de compreendê-los, enquanto instituições culturais decorre dos entendimentos que eles preconizam mediações entre culturas e conhecimentos e, assim, possibilitam a pedagogização dos sujeitos, a partir de diferentes contextos que nos educam, especificamente, neste caso, ambientes não formais de educação ou não escolarizados. Assim, os terreiros, estão sendo entendidos como espaços profícuos às investigações sobre o ensino de história, sem com isso pensar que eles substituem as escolas, porém estão alocados de modo paralelo a estas. Trato-os, então, como campos possíveis para atuação de educadores(as), em diálogo com os saberes destes locais, por

\footnotetext{
${ }^{11}$ Por uma questão de organização os recortes dos Diários de Campo ficaram em destaque dentro de quadros. Além disso, utilizamos fonte tamanho $10 \mathrm{pt}$.
} 
compreender que os espaços não-formais de educação possuem planejamentos, conduzidos por intencionalidades não necessariamente formalizadas (LIBÂNEO, 1998).

$\mathrm{Na}$ educação não formal existe a intencionalidade de educar, a partir de planejamentos que seguem conteúdos específicos que buscam cumprir com alguma organização, respondendo a alguma lógica de ensinamento, fator que implica em reconhecer objetivos diferentes para cada conteúdo (LIBÂNEO, 1998). No entanto, mantem a característica de flexibilidade tanto de espaços, quanto de tempo. Nela, o processo de ensinar é múltiplo, não tendo como característica a adoção de uma sequência, tampouco está preocupada em seguir um sistema com referências generalistas (LIBÂNEO, 1998). Seus conteúdos são abordados de acordo com as necessidades e desenvolvimento dos sujeitos partícipes dos processos educativos. Porém, destacamos, que alguns modelos de educação não formal, podem se assemelhar a formalidade da escola, contudo, ocorrendo em ambientes que não sejam os escolares.

“[...] aqui não é um colégio, mas tudo tem sua hora e momento. Tu nunca pula um fundamento, cada aprendizagem tem sua fase e momento de ritual para acontecer, estar pronto implica em ter aprendido sobre as histórias da religião, das coisas que fazemos no terreiro. Nada é de qualquer jeito, um aprendizado puxa e depende de outro" (ASÉ IJEXÁ - 17/ 07/ 2018).

A educação não formal compreende dentro de suas características uma noção de educação global, que inclua todas as possibilidades de experiência dos sujeitos, reconhecendo que "[...] tais elementos impregnam a própria natureza dos conteúdos e métodos de ensino" (LIBÂNEO, 1998, p. 85). Libâneo (1998) destaca que existem três modalidades de educação (formal, não formal e informal) e educar de modo global seria uma forma de colocar estas concepções em diálogo. Ao considerar essa afirmação mais as experiências dos sujeitos é que se torna possível pensar nos terreiros enquanto espaços educacionais, compreendendo neles, possibilidades de articulação de saberes, sem sobreposição de um, em relação ao outro. Os terreiros então assumem a função de educar, a partir de saberes que orientam não só práticas religiosas, mas modos de ser e estar no mundo e que são marcados por referências a variadas temporalidades, são construídos a partir de referências ao passado, ao histórico, ao mitológico.

Os terreiros, instituições culturais, são conduzidos por pessoas denominadas de mediadores(as) culturais. O que não implica dizer que os(as) dirigentes dos mesmos não possuam formação acadêmica, mas em grifar que não são chamados(as) de professores(as). Enquanto ambientes educativos são também entendidos como locais para experimentação cultural, por um viés de educação não formal, destinados a ensinar o que muitas vezes não se passa nas escolas (LIBÂNEO, 1998). 
"[...] no terreiro tu aprende muita coisa é uma extensão da tua casa e, tens que saber conviver com o que todos sabem, todo mundo aqui aprende e ensina. Aqui, começa pela cozinha, tu precisa saber servir as entidades, depois tem os pontos, as rezas, as dinâmicas da casa, além dos rituais de chegada e saída, as danças, as vidas das entidades, isso fala muito da casa é básico" (NAÇÃO JEJE-IJEXÁ - 30/ 07/ 2018).

Além disso, os terreiros são espaços que podem ser compreendidos como patrimônios ${ }^{12}$ culturais que possuem, dentre seus propósitos, manter memórias, sinalizar a existência de culturas específicas, acolhendo todos(as) aqueles(as) que deles queiram fazer parte ou por eles aprender. Dialogo com Gohn (2005), ao expor que a educação não-formal preconiza processos em três extensões, primeiro porque envolve uma aprendizagem de cunho político dos sujeitos visando a uma educação para cidadania; segundo porque, auxilia na formação para organização em comunidade, uma vez que a aprendizagem parte das práticas de um coletivo específico; terceiro por não desprezar os conteúdos da educação formal, porém, opera com eles em diálogo, a partir de espaços e tempos que compreendam as necessidades dos sujeitos.

Gohn (2005) separa a educação não formal em dois grupos, o primeiro é o da “educação popular", com destaque para educação de jovens e adultos, aquela ocorrida fora do contexto escolar. O segundo grupo é o educação propiciada pela "participação social", baseado na coletividade, em prol da aprendizagem de conteúdos de uma cultura específica, como é o caso dos terreiros, embora não despreze os saberes ensinados nas escolas. Estes grupos demarcam que a educação não formal, não é algo do nosso tempo, ela possui discursos pedagógicos que contemplam desde as culturas iniciais, até as produzidas atualmente, sem que uma anule a outra. Para Garcia (2005) a educação não formal " [...] pode ser a busca de uma outra dimensão educacional, que se diferencia sem a preocupação de negar a educação formal [...] busca considerar contribuições vindas de experiências que não são priorizadas na educação formal" (GARCIA, 2005, p. 27) pode ser pensada por uma característica, a não ser tão verticalidade. Isso porque, ela preconiza interações de diferentes ordens, nas quais os ensinamentos ocorrem em múltiplos vetores e, mais que isso, em um sistema onde todos(as) ensinam todos(as). Nesse caso, existe outro motivo para alocar os terreiros tanto como espaços educativos, quanto como instituições culturais que pedagogizam sujeitos.

\section{O dançado e o apreendido: os ensinamentos por entre as saias e capas...}

\footnotetext{
${ }^{12}$ Afirmar os terreiros como patrimônios é algo advindo de pesquisas realizadas nas páginas do Instituto do Patrimônio Histórico e Artístico Nacional (IPHAN). Contudo, saliento que não me deterei às discussões relacionadas a temática, tampouco busco aprofunda-la na conceituação acerca de patrimônios e processos de patrimonialização, o que faço é sinalizar a existência desses debates.
} 
Expostas estas considerações, afirmamos que nos terreiros, os ensinos, as pedagogias e metodologias, são da ordem da não formalidade, ou como exposto pelos(as) dirigentes dos mesmos, da não escolaridade. A educação não formal está para os terreiros, como os ensinos de danças está para produção dos corpos, com pedagogias que partem de conhecimentos específicos destes locais. No entanto, de qualquer modo, a educação ocorre diretamente nos corpos, sobre eles preconizando certa docilidade (FOUCAULT, 2000). A educação não formal interage com a produção de memórias, advindas das regras que orientam culturas e, assim, os corpos não param de ser produzidos, a partir de influências específicas de cada tempo (SANT'ANNA, 2005). Eles - os corpos são, por assim dizer, pedagogizados o tempo todo, por via da oralidade. Por fim, em relação aos ensinamentos foi possível perceber que os pais ou mães de santo recorrem às mitologias que envolvem os exus e pombagiras desenvolvidos nos Terreiros estudados, nos quais todos(as) ensinam, nestes espaços educativos.

\section{Guias teóricos(as):}

BARBARA, Rosamaria Susanna. A dança das Aiabás: dança, corpo e cotidiano das mulheres de candomblé. Tese de Doutorado em Sociologia. Departamento de Sociologia da Faculdade de Filosofia, Letras e Ciências Humanas. Universidade de São Paulo. São Paulo, 2002. 201 p. Disponível em: $<$ http://www.teses.usp.br/teses/disponiveis/8/8132/tde-09082004-085333/pt-br.php> Acesso em: 20 de maio de 2018.

BARBOSA JÚNIOR, Ademir. Mitologia dos Orixás: lições e aprendizados. São Paulo: Anúbis, 2014.

BARRETO, Débora. Dança... Ensino, Sentido e Possibilidades na Escola. Ed. Autores Associados. $3^{\mathrm{a}}$ ed. 2008.

BOSI, Ecléa. Cultura de massa e cultura popular: leituras de operárias. 12. ed. Petrópolis, RJ: Vozes, 2008.

CAPUTO, Stela Guedes. Educação nos terreiros: e como a escola se relaciona com crianças de candomblé/ Stela Guedes Caputo. - 1. Ed. - Rio de Janeiro: Pallas, 2012.

CARDOSO, Ângelo Nonato Natale. A linguagem dos tambores. Tese de Doutorado em Música/ Etnomusicologia da Universidade Federal da Bahia. Salvador, 2006. (parte $1-256$ p.) e (parte $2-156$ p.) Disponível em:

$<$ https://repositorio.ufba.br/ri/bitstream/ri/9112/1/Tese \%20Angelo\%20Cardoso\%20part e\%201.pdf $>$ Acesso em: 19 de maio de 2018.

CARNEIRO, Edson. Candomblés da Bahia. Rio de Janeiro, Ed. Ouro, 1967. 
COELHO, Juliana de Moraes. Negra, sim: olhares docentes sobre a identidade étnica e a relação com o ensino de Danças Afro na cidade de Pelotas - RS. 2017. 139 f.

Trabalho de Conclusão de Curso (Licenciatura em Dança) - Curso de Licenciatura em Dança, Centro de Artes, Universidade Federal de Pelotas, Pelotas, 2017. Disponível em: $<$ http://wp.ufpel.edu.br/danca/files/2014/06/VERS\%C3\%83O-FINAL-TCC-JUCOELHO-.pdf $>$ Acesso em: 15 de maio de 2018.

CUCHE, Denys. A noção de cultura nas Ciências Sociais. Bauru: EDUSC, 1998.

DA SILVA, Mary Anne Vieira. Xirê - A festa do Candomblé e a formação dos "entrelugares". Habitus. Goiânia, vol. 8, nº. 1/2, pp. 99-117, jan./dez. 2010. Disponível em: $<$ http://seer.ucg.br/index.php/habitus/article/viewFile/2172/1340> Acesso em: 28 de maio de 2018.

FILHO, Antônio Neves de Araújo. Protestos e manifestações afro-brasileiras na música negra baiana nos anos de 1980. Trabalho de Conclusão de Curso (modalidade Artigo), curso de Especialização em História e Cultura Africana e Afro-Brasileira, da Universidade Federal do Rio Grande do Norte, Centro de Ensino Superior do Seridó, Campus de Caicó. 2016. 50f. Disponível em:

$<$ https://monografias.ufrn.br/jspui/bitstream/123456789/2515/1/ARTIGO\%20ESPECIA LIZA\%C3\%87\%C3\%83O.pdf> Acesso em: 27 de maio de 2018.

FOUCAULT, Michel. Em defesa da Sociedade: curso no Collége de France. [Trad.] GALVÃO, M. E. A. P. São Paulo: WMF Martins Fontes, 2005.

FOUCAULT, Michel. A arqueologia do saber. Rio de Janeiro: Forense-Universitária. $2^{\mathrm{a}}$ e $6^{\mathrm{a}}$ ed. [Trad.] NEVES, L. F. B. 2000.

GARCIA, Valéria Aroeira. Um sobrevôo: o conceito de educação não formal. In: PARK, M. B.; FERNANDES, R. S. [Orgs.]. Educação Não-Formal: Contextos, Percursos e Sujeitos. Campinas, SP: Unicamp - Editora Setembro, 2005.

GEERTZ, Clifford. A interpretação das culturas. Rio de Janeiro: LTC, 2008.

GOHN, Maria da Glória. Educação Não-Formal e Cultura Política. 3 ed. São Paulo: Cortez, 2005 (Coleção questões da Nossa época; v. 71).

GUERRA, Denise. Um olhar sobre a cultura corporal de movimento afro-brasileira construída a partir da corporeidade africana. Revista África e Africanidades - Ano I n. 2 - Agosto. 2008. Disponível em:

$<\mathrm{http}$ ://www.africaeafricanidades.com.br/documentos/um_olhar_sobre_a_cultura_corpo ral_de_movimento_afro_brasileiro.pdf $>$ Acesso em: 26 de maio de 2018.

GUERREIRO, Goli. A trama dos tambores: A música afro-pop de Salvador. Coleção Todos os Cantos. 2. ed. São Paulo: Editora 34, 2010.

HENNING, Clarissa Corrêa; HENNING, Paula Corrêa. Sobre verdades inventadas e mentiras potentes: práticas de si como espaço de resistência. In.: HENNING, P. [Org.]. Cultura, ambiente e sociedade. Rio Grande: Universidade Federal de Rio Grande, 2012. pp. 9-32.

IKEDA, Alberto. O Ijexá no Brasil: rítmica dos deuses nos terreiros, nas ruas e palcos da música popular. Revista USP. São Paulo, nº 111, pp. 21-36. 
Outubro/Novembro/Dezembro. 2016. Disponível em:

$<$ http://www.revistas.usp.br/revusp/article/viewFile/127596/124647> Acesso em: 19 de junho de 2018.

LIBÂNEO, José Carlos. Pedagogia e pedagogos para quê? São Paulo: Cortez, 1998.

LOPES, Nei. A presença africana na música popular brasileira. In. Revista Espaço Acadêmico. Universidade Federal de Uberlandia (UFU) Uberlândia, $n^{\circ}$. 50. julho\ julho, 2005. Disponível em: <https://meujazz.files.wordpress.com/2010/01/lopes-nei-apresenca-africana-na-musica-popular-brasileira.pdf $>$ Acesso em: 17 de maio de 2018.

MACHADO, Felipe. Entre rodas de dança e coreografias: notas para um pensamento dançarino. pp. 15-23. Horizonte de la Ciencia vol. 4 (nº . 7), diciembre 2014. Disponível em:

$<$ http://www.uncp.edu.pe/revistas/index.php/horizontedelaciencia/article/view/103> Acesso em: 21 de maio de 2018.

MARQUES, Isabel A. Dançando na escola. Motriz - Vol. 3, No. 1, Junho/1997, pp. 20 - 28. Disponível em: <http://www.rc.unesp.br/ib/efisica/motriz/03n1/artigo3.pdf $>$ Acesso em: 11 de julho de 2018.

MIRANDA, Eduardo Oliveira. O negro do Pomba quando sai da Rua Nova, ele traz na cinta uma cobra coral: os desenhos dos corpos-territórios evidenciados pelo Afoxé Pomba de Malê. Dissertação (mestrado) - Universidade Estadual de Feira de Santana Programa de Pós-Graduação em Desenho, Cultura e Interatividade. Feira de Santana, 2014. 168 f. Disponível em: <http://tede2.uefs.br:8080/handle/tede/97?locale=pt_BR $>$ Acesso em: 28 de maio de 2018.

PRANDI, Reginaldo. Mitologia dos Orixás. São Paulo: Companhia das Letras, 2016.

PRANDI, Reginaldo. Segredos guardados: Orixás na alma brasileira. São Paulo: Companhia das letras, 2005. pp. 175-187. Disponível em: $<$ www.fflch.usp.br/sociologia/prandi/musicafe.rtf $>$ Acesso em 20 de maio de 2018.

SANT'ANNA, Denise. Cuidado de Si e Embelezamento Feminino: fragmentos para uma história do corpo no Brasil. In: [Org.]. Políticas do corpo: elementos para uma história das práticas corporais. $2^{\mathrm{a}}$ ed. São Paulo: Estação liberdade, 2005. pp. 121139.

SANTOS, Rosalira Oliveira dos; GONÇALVES, Antonio Giovanni Boaes. A natureza e seus significados entre adeptos das religiões afro-brasileiras. Anais do III Encontro Nacional do GT História das Religiões e das Religiosidades - ANPUH. In.: Revista Brasileira de História das Religiões. Maringá (PR) vol. III, nº. 9, jan/2011.

SILVA, Tomaz Tadeu da. Documentos de identidade; uma introdução às teorias do currículo. $3^{\mathrm{a}}$ Ed. - Belo Horizonte: Autêntica, 2009. 156 p.

SILVEIRA, Rozana Aparecida; CARDOSO, Fernando Luiz; SABBAG, Samantha. Relações de gênero e relação corporal entre praticantes de axé e hip hop. In. Anais. Seminário Internacional Fazendo Gênero 8. (Florianópolis, de 25 a 28 de agosto de 2008). Disponível em: http://www.fazendogenero.ufsc.br/8/sts/ST22/Silveira-CardosoSabbag_22.pdf. Acesso em: 20 de fevereiro de 2018. 
SILVEIRA, Tatiana Teixeira. O Movimento das Aulas na Palavra Escrita. In: PARDO, Eliane; WÜRDIG, Rogério \& SILVEIRA, Tatiana. A Formação En(Cena) - Jogos de Escrita IV. Pelotas: Gráfica da UFPel, 2002.

SOARES, Carmen. A educação do corpo e o trabalho das aparências: o predomínio do olhar. In: ALBUQUERQUE JÚNIOR, Durval et. al. Cartografia de Foucault. Belo Horizonte: Autêntica, 2008. pp. 69-82.

SOUZA, Edilson Fernandes. Etnografia e história da dança litúrgica e artística no Rio de Janeiro. In. Anais. VII Congresso brasileiro de história da Educação Física, esportes, lazer e dança (Gramado - RS). Porto Alegre: UFRGS $\backslash$ ESEF, 2000. pp. 304-308. Disponível em: < http://www.lume.ufrgs.br/handle/10183/99134> Acesso em: 27 de maio de 2018.

SOUZA, Maiza Ribeiro de; ARAÚJO, Risoneide Silva de; SANTANA, Rosemere Olímpio de. Entre ritmos e músicas: discutindo a identidade afro-brasileira na docência compartilhada. In.: ANAIS. e-ISSN: 2359-2796, v. 17, n. 1, 2016. XVII Encontro Estadual de História - ANPUH-PB. Disponível em:

$<$ http://www.ufpb.br/evento/lti/ocs/index.php/xviieeh/xviieeh/paper/viewFile/3276/269 3> Acesso em: 30 de maio de 2018.

STEINBERG, Susan; KINCHELOE, Joe. [Orgs.] Cultura infantil: a construção corporativa da infância. Rio de Janeiro: Ed. Civilização Brasileira, 2001.

STRAZZACAPPA, Marcia. A educação e a fábrica de corpos: a dança na escola. Cadernos CEDES, Campinas, v. 21, n. 53, pp. 69-83, abr. 2001.

TINHORÃO, José Ramos. Os sons dos negros no Brasil. Cantos, danças e folguedos: origens. São Paulo: Editora 34, 2012 (3 $3^{\text {a }}$ Edição).

VEIGA-NETO, Alfredo; FILHO, Alípio de Souza e JÚNIOR, Durval Muniz de Albuquerque [Orgs.]. Cartografias de Foucault. Autêntica Editora. 1ª ed. 2008.

\section{Outros guias:}

BLOG - AUM MAGIC - uma viagem ao mundo mágico da natureza e espiritualidade humana na busca de um conhecimento profundo sobre o significado da vida. A dança na Umbanda, Candomblé, Dança afro, dança e religião. Disponível em: $<$ http://aumagic.blogspot.com.br/2017/02/a-danca-na-umbandacandombledanca.html $>$ Acesso em: 18 de maio de 2018.

BLOG - Afrobrasileirismo. Logunedé. FONSECA, Daniel. Disponível em: $<$ http://afrobrasileirismo.blogspot.com.br/2014/02/logunede.html> Acesso em: 26 de maio de 2018.

BOLG - Grupo de Umbanda/ Triângulo da Fraternidade. Rezas cantadas para os orixás. Disponível em: $<\mathrm{http}: / / \mathrm{www}$.triangulodafraternidade.com/ $>$ Acesso em: $22 \mathrm{de}$ junho de 2018. 
BLOG - Histórias Brasileiras. SIMAS, Luiz Antônio. A música sacra dos terreiros - o Ijexá. Disponível em: < http://hisbrasileiras.blogspot.com.br/2010/12/ritmos-sacros-dosterreiros-o-ijexa.html> Acesso em: 27 de maio de 2018.

BLOG - NAÇÃO JÊJE-IJEXÁ RS. Ossãnha. Disponível em:

$<$ http://nacaojeje.blogspot.com.br/2012/04/ossanha.html> Acesso em: 28 de maio de 2018.

BLOG - NUNES, Isaac. Ijexá Histórico. Disponível em:

$<$ https://www.youtube.com/watch?v=TrX9VGXC1Ws $>$ Acesso em: 29 de maio de 2018.

BLOG - Opotun Vinícius. Ijesa de Logun Ede, Não é o Mesmo Ijesa de Òsun?

Disponível em: $<$ http://opotunvinicius.blogspot.com.br/2011/08/ijesa-de-logun-ede-naoe-o-mesmo-ijesa.html> Acesso em: 28 de maio de 2018.

BLOG - Ouro de Tolo. MIGÃO, Pedro. A música sacra dos terreiros - o Ijexá.

Disponível em: <http:/www.pedromigao.com.br/ourodetolo/2010/12/a-musica-sacrados-terreiros-o-ijexa/> Acesso em: 26 de maio de 2018.

BLOG - REGO, José Carlos. A Dança dos Orixás - sensual, guerreira manhosa, a fascinante dança dos orixás. In.: Blog Memórias do Samba. Disponível em:

$<$ http://www.academiadosamba.com.br/memoriasamba/artigos/artigo-020.htm $>$ Acesso em: 25 de maio de 2018.

BLOG - Ylê Ijexá Oxalá Onifan - Pai Adriano de Oxalá. Disponível em: $<$ http://yleoxalaonifan.blogspot.com.br/> Acesso em: 22 de maio de 2018.

CANAL - Cia Aie Orum - YouTubeBR. Disponível em:

$<$ https://www.youtube.com/channel/UCvBCdNiEA17JnJ4SjwNq14g> Acesso em: 25 de maio de 2018.

SITE - Casa Iemanjá Iassobá. Logum Edé. Disponível em:

$<$ http://www.casaiemanjaiassoba.com.br/LogumEde.html $>$ Acesso em: 25 de maio de 2018.

SITE - Casa Iemanjá Iassobá. Ossãe. Disponível em:

$<$ http://www.casaiemanjaiassoba.com.br/ossae.html> Acesso em: 25 de maio de 2018.

SITE - Casa Iemanjá Iassobá. Oxumarê. Disponível em:

$<$ http://www.casaiemanjaiassoba.com.br/Oxumare.html> Acesso em: 25 de maio de 2018 .

VÍDEO - Balé de pé no chão/ Mercedes Baptista - 2005 - Disponível em:

$<$ https://www.youtube.com/watch? v=kb2tSAMFQuY> Acesso em: 18 de maio de 2018.

VÍDEO - CULTNE DOC - Prêmio Afro - Homenagem a Mercedes Baptista.

Disponível em: <https://www.youtube.com/watch?v=JlnsgDnXXCQ $>$ Acesso em: 18 de maio de 2018.

VÍDEO - Mercedez Baptista 1 - Disponível em:

$<$ https://www.youtube.com/watch?v=TNuo9Cgkz6o $>$ Acesso em: 18 de maio de 2018. 


\section{PÉDAGOGIQUE PRATIQUE EN DANSE:}

L'AS DE IJESHA DE LA PRODUCTION DE CONNAISSANCES DANS LES ARTS

\section{Résumé}

Ilexá est une ville de l'état d'Osun. En plus d'autres événements culturels couverts dans le sol brésilien la Ijesha présente des caracteres autre que pratiqué dans les sols africains. Tactile sacrées du Candomblé, il est probablement le plus doux et cadencé, cadrage Phil et danse sensuelle d'Oshun et Logum. L'écriture de cette partie du texte de cette prémisse à penser une pratique pédagogique dans les danses africaines.

\section{Mots-clés}

Enseignement de la danse. Ijesha. Danses africaines. Éducation. Nickie Wang/ Corporalités

\section{ANEXO}

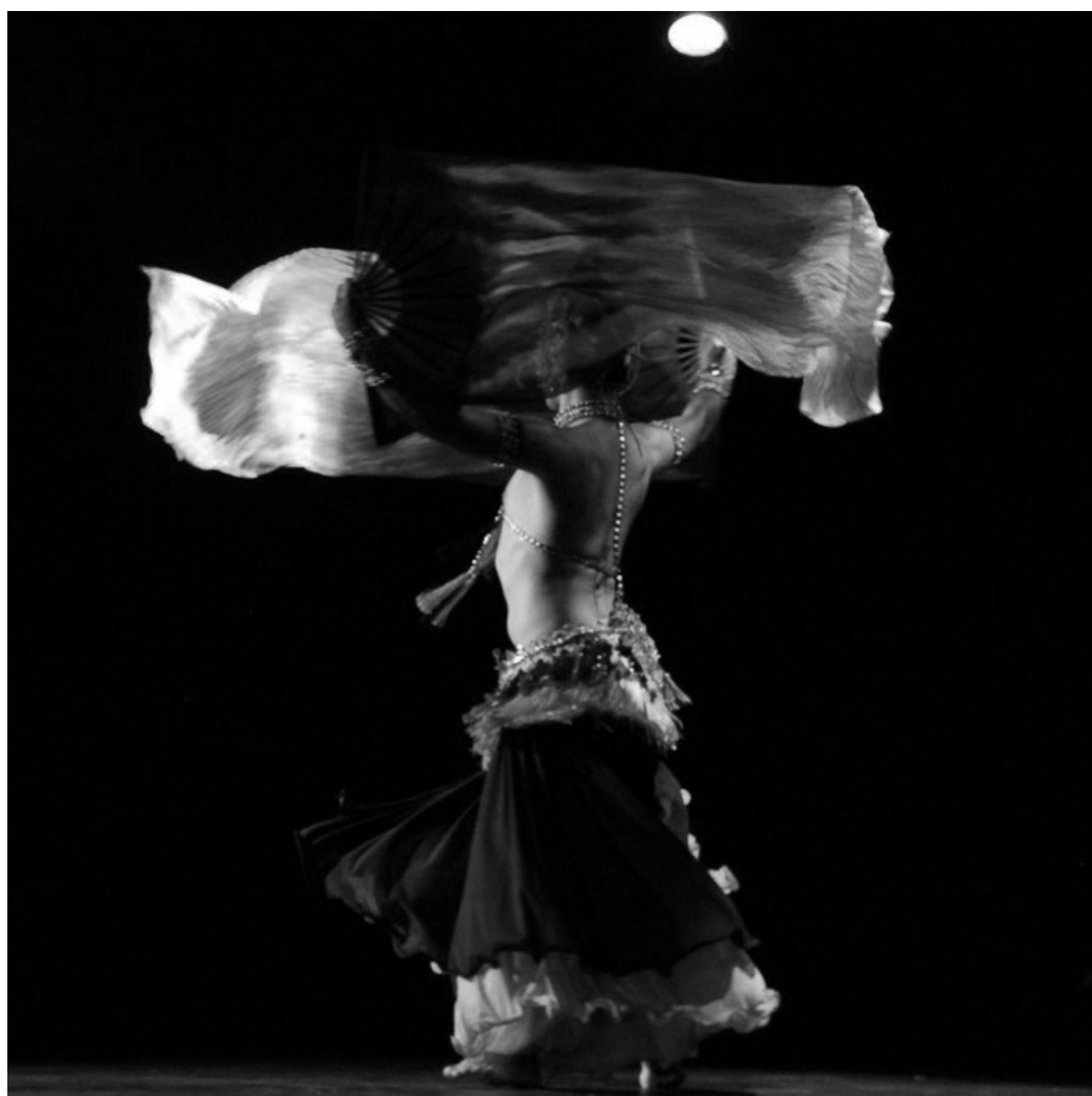

